\title{
ANALISIS RESPON MAHASISWA TERHADAP PEMBELAJARAN MENGGUNAKAN BORNEO E-LEARNING PADA MATA KULIAH BAHASA INGGRIS MATEMATIKA
}

\author{
Ika Noviantari ${ }^{1}$ \\ ${ }^{1}$ Jurusan Pendidikan Matematika Universitas Borneo Tarakan \\ ${ }^{1}$ ika_viviantari@borneo.ac.id
}

\begin{abstract}
E-learning learning has been widely applied with the blended learning system, but in times of pandemic now learning is completely online. The software application used for electronic learning, training, and on the network is the Learning Management System (LMS). The LMS-based learning tool developed by the Center for Curriculum Development and Learning of the University of Borneo Tarakan is Borneo e-learning (Bel). The use of Bel in learning requires monitoring and evaluation to see the success of learning by seeing student responses. His study aims to see student responses to learning English mathematics using a Bel. This research method is a descriptive qualitative method, with a purposive sampling technique. A sample of 54 students with a questionnaire instrument. The student acceptance indicator for learning using the bell shows that the average student agreed to $92.58 \%$, and disagree with $7.42 \%$. While the indicator of ease of use of the bell, the average student approves of $91.84 \%$, and $8.16 \%$ disagrees. So it can be concluded that the student's response to learning using Borneo e-learning in English mathematics is positive. So that it can be used for online lectures on subsequent mathematics English courses.
\end{abstract}

Keywords: E-learning, student response, Bel, English math

\begin{abstract}
Abstrak
Pembelajaran e-learning sudah banyak diterapkan dengan sistem pembelajaran blended learning, namun di masa pandemi sekarang pembelajaran sepenuhnya secara online. Aplikasi lunak yang digunakan untuk pembelajaran elektronik, pelatihan, dan didalam jaringan adalah Learning Management System (LMS). Sarana pembelajaran berbasis LMS yang dikembangkan oleh Pusat Pengembangan Kurikulum dan Pembelajaran Universitas Borneo Tarakan adalah Borneo e-learning (Bel). Penggunaan Bel dalam pembelajaran diperlukan monitoring dan evaluasi untuk melihat keberhasilan pembelajaran dengan melihat respon mahasiswa. Penelitian ini bertujuan untuk melihat respon mahasiswa terhadap pembelajaran bahasa Inggris matematika menggunakan Bel. Metode penelitian ini metode deskriptif kualitatif, dengan teknik pengambilan purposive sampling. Sampel 54 mahasiswa dengan instrumen kuisioner. Indikator penerimaan mahasiswa terhadap pembelajaran menggunakan Bel menunjukkan rata-rata mahasiswa menyatakan setuju sebesar $92,58 \%$, dan tidak setuju sebesar $7,42 \%$. Sedangkan indikator kemudahan penggunaan dari Bel rata-rata mahasiswa menyetujui sebesar $91,84 \%$, dan sebesar $8,16 \%$ tidak menyetujui. Sehingga dapat disimpulkan bahwa respon mahasiswa terhadap pembelajaran menggunakan borneo e-learning pada mata kuliah bahasa inggris matematika positif. Sehingga dapat digunakan untuk perkuliahan online mata kuliah bahasa Inggris matematika selanjutnya.
\end{abstract}

Kata kunci: E-learning, respon mahasiswa, Bel, bahasa Inggris matematika

Cara Menulis Sitasi: Noviantari, I. (2020). Analisis Respon Mahasiswa Terhadap Pembelajaran Menggunakan Borneo E-Learning Pada Mata Kuliah Bahasa Inggris Matematika. Mathematic Education and Aplication Journal, 2(2), 1-7.

Seiring dengan kemajuan teknologi dan informasi, mahasiswa sebagai generasi penerus harus mampu menyikapi dan memanfaatkannya sebagai perkembangan dalam dunia pendidikan. Sistem pembelajaran elektronik/e-pembelajaran yang biasa disebut E-learning merupakan akibat dari 
perkembangan teknologi dan informasi tersebut (Arifin \& Ekayati, 2019). Pembelajaran yang menggunakan alat elektronik seperti laptop, $\mathrm{hp}$, tablet dan lainnya dalam pelaksanaannya disebut pembelajaran e-learning. Pembelajaran e-learning sudah banyak diterapkan dengan sistem pembelajaran blended learning. Materi yang belum tersampaikan di dalam kelas tatap muka dapat dilengkapi dengan pembelajaran blended learning, sehingga tidak seluruh pembelajaran tatap muka digantikan dengan pembelajaran secara online (Bibi \& Jati, 2015). Namun, di masa pandemi sekarang pembelajaran sepenuhnya secara online. Pembelajaran secara online sebenarnya memberikan peluang kepada mahasiswa untuk memperoleh dan mencari informasi secara luas, dimana saja dan kapan saja.

Aplikasi lunak pertama kali muncul pada tahun 1997 yang digunakan untuk pembelajaran elektronik, pelatihan, dan didalam jaringan adalah Learning Management System (LMS) (Simanihuruk et al., 2019). Keunggulan LMS yaitu dalam hal pengelolaan pembelajaran yang berbasis web dimana penilaian, menyediakan materi dengan berbagai format. Salah satunya platformnya adalah moodle yang dapat dimodifikasi sesuai dengan yang dibutuhkan dalam pembelajaran (Rizal \& Walidain, 2019). Sarana pembelajaran berbasis LMS yang dikembangkan oleh Pusat Pengembangan Kurikulum dan Pembelajaran Universitas Borneo Tarakan adalah Borneo $e$ learning (Bel). Platform LMS yang digunakan dalam Bel adalah moodle (Darmayasa \& Aras, 2019). Dosen dan mahasiswa yang baru pertama kali menggunakan moodle dapat mempelajari panduan penggunaan manual Bel yang dibuat oleh pengembang. Dosen dan mahasiswa dapat mengakses Bel dengan dua cara yaitu dengan mengakses https:/learn.borneo.ac.id/ atau htttp:/kuliah.borneo.ac.id, setelah itu membuat akun untuk log in. Mahasiswa dapat masuk ke dalam kelas Bel dengan memasukkan enrollment key kelas yang diberikan oleh masing-masing dosen pengampu mata kuliah yang menggunakan Bel. Fitur yang disediakan oleh moodle yaitu dosen dapat menyematkan sumber dan media pembelajaran yang berupa $e$-book, handout, lembar kerja mahasiswa, video pembelajaran, dan media belajar lain (mentimeter, padlet, pear deck dll) dimana akan diakses dan digunakan mahasiswa dalam perkuliahan secara online.

Pendidikan matematika merupakan salah satu jurusan yang mengalami kesulitan dalam pembelajaran secara online. Dosen harus dapat menyampaikan materi perkuliahan kepada mahasiswa dengan kualitas yang sama dengan tatap muka. Hal ini disebabkan dalam perkuliahan di jurusan matematika tidak lepas dari pengaplikasian rumus. Perkuliahan dalam masa pandemi Covid 19 ini mengharuskan semua pembelajaran secara online. Pembelajaran secara online di jurusan pendidikan matematika sebenarnya bukan hal yang baru. Beberapa mata kuliah sudah menerapkan pembelajaran secara blended learning. Salah satunya pada mata kuliah bahasa Inggris Matematika.

Mata kuliah bahasa Inggris matematika yang sebelumnya menerapkan pembelajaran blended learning, dan sekarang pembelajaran full online didalam materinya tidak hanya penyampaian istilah dan simbol matematika dalam bahasa Inggris, juga terdapat beberapa aspek yang dilihat antara lain reading, speaking, listening, dan writing. Dalam pelaksanaan pembelajaran, pemberian materi, 
pemberian dan pengumpulan tugas, dan penilaian semua diupload dan disematkan di Bel. Oleh karena digunakan BEL dalam pembelajaran full online maka diperlukan monitoring dan evaluasi untuk melihat keberhasilan pembelajaran. Menganalisis respon mahasiswa merupakan salah satu bentuk dari mengevaluasi pembelajaran. Keberhasilan pembelajaran secara maksimal dapat terlihat dari respon mahasiswa (Hartati, 2017). Oleh karena itu penelitian ini bertujuan untuk melihat respon mahasiswa terhadap pembelajaran bahasa Inggris matematika menggunakan Bel diperlukan. Dosen dapat menggunakan hasil penelitian ini untuk menentukan apakah akan menggunakan Bel dalam perkuliahan online, baik untuk mata kuliah bahasa Inggris matematika maupun mata kuliah yang lainnya.

\section{METODE}

Metode deskriptif kualitatif digunakan dalam penelitian ini. Penelitian ini dilaksanakan di jurusan pendidikan matematika Fakultas Keguruan dan Ilmu Pendidikan (FKIP) Universitas Borneo Tarakan. Populasi dalam penelitian ini adalah semua mahasiswa yang sudah/sedang mengambil mata kuliah bahasa Inggris matematika menggunakan media Bel. Teknik pengambilan sampel menggunakan purposive sampling, agar kriteria sesuai dengan yang diharapkan dengan sampel sebanyak 54 mahasiswa. Instrumen penelitian dalam pengumpulan data menggunakan kuisioner dan wawancara. Kuisioner disebarkan menggunakan google form, sedangkan wawancara dilakukan menggunakan zoom meeting, untuk memperoleh tanggapan secara langsung mahasiswa. Hal ini dirasa lebih efektif karena pembelajaran secara online di masa pandemi covid. Indikator kuisioner dibagi menjadi dua yaitu penerimaan mahasiswa terhadap pembelajaran menggunakan Bel, dan kemudahan penggunaan dari Bel. Adapun instrumen pernyataan dalam kuisioner sebagai berikut:

Tabel 1. Pernyataan Respon Mahasiswa Terhadap Pembelajaran Menggunakan Borneo E-Learning Pada Mata Kuliah Bahasa Inggris Matematika

\begin{tabular}{|c|c|c|}
\hline Indikator & $\mathrm{No}$ & Pernyataan \\
\hline \multirow[t]{5}{*}{$\begin{array}{l}\text { Penerimaan mahasiswa terhadap } \\
\text { pembelajaran menggunakan Bel }\end{array}$} & 1 & $\begin{array}{l}\text { Mahasiswa senang menggunakan Bel dalam } \\
\text { perkuliahan bahasa Inggris matematika }\end{array}$ \\
\hline & 2 & $\begin{array}{l}\text { Mahasiswa tertarik dan termotivasi dalam } \\
\text { perkuliahan bahasa } \\
\text { menggunakan Bel }\end{array}$ \\
\hline & 3 & $\begin{array}{l}\text { Bel sangat bermanfaat dalam pelaksanaan } \\
\text { perkuliahan bahasa Inggris matematika }\end{array}$ \\
\hline & 4 & $\begin{array}{l}\text { Bel memberikan pengalaman baru dalam } \\
\text { pembelajaran secara online }\end{array}$ \\
\hline & 5 & $\begin{array}{l}\text { Pembelajaran bahasa Inggris matematika melalui } \\
\text { Bel membuat mahasiswa disiplin dalam } \\
\text { mengerjakan tugas }\end{array}$ \\
\hline \multirow[t]{2}{*}{ Kemudahan penggunaan dari Bel } & 6 & $\begin{array}{l}\text { Mahasiswa mudah mengakses materi perkuliahan } \\
\text { bahasa Inggris matematika }\end{array}$ \\
\hline & 7 & Sumber belajar yang diupload/disematkan di Bel \\
\hline
\end{tabular}




\begin{tabular}{|c|c|l|}
\hline \multirow{2}{*}{} & & $\begin{array}{l}\text { meningkatkan pemahaman materi dalam } \\
\text { perkuliahan bahasa Inggris matematika }\end{array}$ \\
\cline { 2 - 4 } & 8 & $\begin{array}{l}\text { Mahasiswa lebih suka mengirimkan tugas berupa } \\
\text { video dalam Bel dibandingkan tampil langsung } \\
\text { menggunakan video conference }\end{array}$ \\
\hline & 9 & $\begin{array}{l}\text { Pemberian materi, dan pengumpulan tugas lebih } \\
\text { mudah, serta memperoleh pengumuman secara } \\
\text { cepat menggunakan Bel }\end{array}$ \\
\cline { 2 - 4 } & 10 & Tampilan Bel menarik, jelas, dan mudah dipahami \\
\hline
\end{tabular}

Sedangkan untuk wawancara, pertanyaan untuk memperdalam yaitu "apakah kendala yang dihadapi pada saat pembelajaran bahasa Inggris matematika menggunakan Bel?". Analisis data yang diperoleh dengan menginformasikan dengan narasi data yang sudah disajikan dalam bentuk tabulasi dan persentase, kemudian mengintrepetasikannya.

\section{HASIL DAN PEMBAHASAN}

Data hasil kuisioner yang sudah disebarkan melalui google form kepada 54 mahasiswa, dihitung dan tabulasi ke dalam bentuk tabel 2 berikut ini:

Tabel 2. Hasil Respon Mahasiswa Respon Mahasiswa Terhadap Pembelajaran Menggunakan Borneo E-Learning Pada Mata Kuliah Bahasa Inggris Matematika

\begin{tabular}{|c|c|c|c|c|}
\hline \multirow{2}{*}{ Pernyataan } & \multicolumn{3}{|c|}{ Respon Mahasiswa } \\
\cline { 2 - 3 } & Setuju & Tidak Setuju & Setuju & Tidak Setuju \\
\hline 1 & $94,4 \%$ & $5,6 \%$ & & \\
\hline 2 & $88,9 \%$ & $11,1 \%$ & \multirow{3}{*}{$92,58 \%$} & \multirow{2}{*}{$7,42 \%$} \\
\hline 3 & $94,4 \%$ & $5,6 \%$ & & \\
\hline 4 & $100 \%$ & $0 \%$ & & \\
\hline 5 & $85,2 \%$ & $14,8 \%$ & & \multirow{2}{*}{$8,16 \%$} \\
\hline 6 & $92,6 \%$ & $7,4 \%$ & & \\
\hline 7 & $96,3 \%$ & $3,7 \%$ & & \\
\hline 8 & $85,2 \%$ & $14,8 \%$ & & \\
\hline 9 & $90,7 \%$ & $9,3 \%$ & & \\
\hline 10 & $94,4 \%$ & $5,6 \%$ & & \\
\hline Rata-rata & $92,21 \%$ & $7,79 \%$ & & \\
\hline
\end{tabular}

Pada pernyataan nomor 1 mahasiswa senang menggunakan Bel dalam perkuliahan bahasa Inggris matematika menunjukkan mahasiswa menjawab setuju sebesar 94,4\% atau sebanyak 51 mahasiswa setuju, dan hanya 3 mahasiswa atau 5,5\% yang tidak setuju. Pernyataan nomor 2 sebanyak 88,9\% atau sebanyak 48 mahasiswa menyatakan setuju, dan 6 mahasiswa atau 11,1\% menyatakan tidak setuju dalam hal ketertarikan dan termotivasi dalam perkuliahan bahasa Inggris matematika menggunakan Bel. Pernyataan nomor 3 sebanyak 94,4\% atau 51 mahasiswa merasa bahwa Bel sangat bermanfaat dalam pelaksanaan perkuliahan bahasa Inggris matematika, dan hanya 3 mahasiswa yang tidak setuju dengan pernyataan tersebut. Pernyataan nomor 5 semua mahasiswa setuju Bel memberikan 
pengalaman baru dalam pembelajaran secara online. Mahasiswa setuju pernyataan nomor 6 sebesar 92,6\% atau 50 mahasiswa merasa mudah mengakses materi perkuliahan bahasa Inggris matematika, sedangkan ada 4 mahasiswa atau 7,4\% merasa sulit. Sebesar 96,3\% atau 52 mahasiswa menyetujui sumber belajar yang diupload/disematkan di Bel meningkatkan pemahaman materi dalam perkuliahan bahasa Inggris matematika, dan hanya 2 mahasiswa atau 3,7\% tidak menyetujui pernyataan nomor 7 tersebut. Sebesar 85,2\% atau 46 mahasiswa menyetujui lebih suka mengirimkan tugas berupa video dalam Bel dibandingkan tampil langsung menggunakan video conference pada pernyataan nomor 8 , dan sebanyak 8 mahasiswa atau 14,8\% tidak setuju. Pernyataan nomor 9 yaitu pemberian materi, dan pengumpulan tugas lebih mudah, serta memperoleh pengumuman secara cepat menggunakan Bel disetujui sebesar 90,7\% atau 49 mahasiswa, dan 5 mahasiswa yang tidak setuju dengan pernyataa tersebut. Sebesar 94,4\% atau 51 mahasiswa menyetujui bahwa tampilan Bel menarik, jelas, dan mudah dipahami, sedangkan 3 mahasiswa merasa sebaliknya.

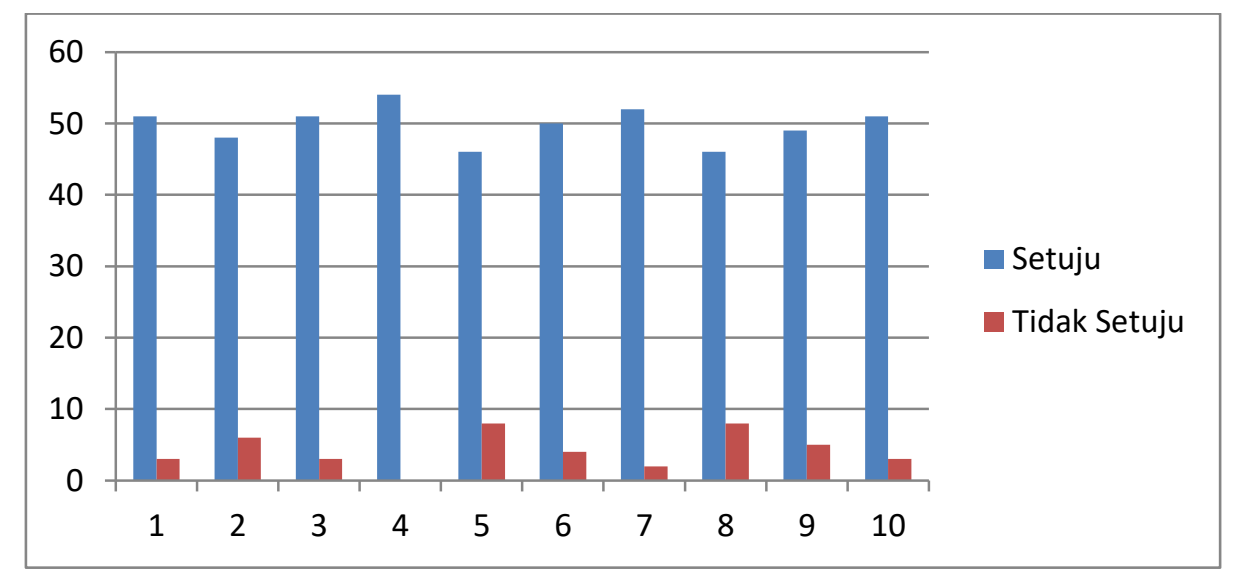

Gambar 1. Hasil respon mahasiswa respon mahasiswa terhadap pembelajaran menggunakan borneo e-learning pada mata kuliah bahasa inggris matematika

Rata-rata penerimaan mahasiswa terhadap pembelajaran menggunakan Bel adalah 92,58\%, dan rata-rata kemudahan penggunaan dari Bel adalah 91,84\%. Dan secara keseluruhan rata-rata tingkat persetujuan mahasiswa terhadap pernyataan adalah 92,21\% sehingga dapat disimpulkan dari data kuisioner tersebut respon mahasiswa terhadap pembelajaran menggunakan borneo e-learning pada mata kuliah bahasa inggris matematika adalah positif dilihat dari indikator penerimaan dan kemudahan penggunaan Bel.

Aspek penerimaan mahasiswa terhadap pembelajaran menggunakan Bel salah satunya adalah meningkatkan kedisiplinan dalam pengumpulan tugas, dalam Bel dapat diatur waktu pengumpulan tugas, apabila ada mahasiswa yang terlambat mengumpulkan tugas maka akan muncul keterangannya. Selain itu juga terdapat fitur pengaturan waktu untuk memunculkan materi, tugas, bahkan penilaian akhir. Sehingga mahasiswa harus mengakses sesuai dengan waktu yang sudah disepakati, jika tidak maka akan terlewat, mahasiswa akan terlatih rasa tanggung jawab dan disiplinnya. Hal ini sesuai dengan penjelasan (Ekayati, 2018). Motivasi pembelajaran dapat muncul dengan adanya sumber 
belajar yang baru seperti mentimeter, padlet yang sebelumnya tidak digunakan dalam pembelajaran tatap muka. Padlet digunakan seperti chat whatsaapp sehingga memudahkan dalam komunikasi secara langsung karena mahasiswa lebih tertarik terhadap tampilan yang sudah biasa mereka lihat dan gunakan. Manfaat penggunaan Bel dalam pembelajaran bahasa Inggris matematika tentunya karena perkuliahan dilaksanakan secara online. Bel dipilih karena beberapa pertimbangan dan penyesuaian karakteristik materi yang akan diberikan dalam perkuliahan tentunya.

Segi kemudahan penggunaan dari Bel, materi dan sumber belajar yang akan diberikan sudah disematkan/ditempel sebelumnya oleh pengampu. Bahkan fitur pendukung chat, live diskusi yang tampilannya seperti whatsaap bisa disematkan. Mahasiswa dapat mengakses dan mendownloadnya kapan saja. Pengumpulan tugas seperti video dan rekaman suara juga sudah tersedia dalam fitur Bel. Mahasiswa bisa langsung mengupload video, suara, foto bahkan file dengan semua format tanpa perlu mengirim melalui email. Semua tersimpan dalam sistem Bel, mahasiswa bisa mendownloadnya kembali, atau mengirim ulang. Tampilan dasar moodle yang dimodifikasi menarik dengan bahasa yang mudah dipahami, dan terstruktur semua tersedia. Hal ini sesuai dengan penjelasan Dian Nataria Oktaviani dkk dalam peelitiannya yaitu ketersediaan fitur moodle cukup membantu dalam kegiatan perkuliahan (Oktaviani et al., 2018).

Pembelajaran pada masa pendemi ini dilaksanakan secara online, dalam penelitian ini ditemukan bahwa bahwa kendala utama yang dialami selama perkuliahan bahasa Inggris matematika menggunakan Bel adalah masalah jaringan yag tiba-tiba hilang, dan kurangnya paket data mahasiswa karena penggunaan media pembelajaran yang berbeda-beda antara dosen yang satu dengan yang lain. Ini sesuai dengan penelitian yang dilakukan Asih Riyanti dan Cici Winda Paramida bahwa kendala yang dihadapi mahasiswa FKIP dalam pembelajaran online adalah jaringan internet yang kurang stabil, kurangnya paket data, jaringan listrik yang sering padam (Riyanti \& Paramida, 2020). Selain itu mahasiswa merasa waktu yang ada pada sistem Bel tidak sesuai dengan real time, ada perbedaan waktu sekitar 15 menit waktu di Bel lebih cepat, sehingga banyak mahasiswa yang terlambat absensi. Dalam penelitian ini juga ditemukan bahwa, server Bel sering down dan bertepatan dengan waktu pengumpulan tugas, sehingga mahasiswa kebingungan saat akan mengupload tugas.

\section{KESIMPULAN}

Indikator penerimaan mahasiswa terhadap pembelajaran menggunakan Bel menunjukkan ratarata mahasiswa menyatakan setuju sebesar $92,58 \%$, dan tidak setuju sebesar 7,42\%. Sedangkan indikator kemudahan penggunaan dari Bel rata-rata mahasiswa menyetujui sebesar $91,84 \%$, dan sebesar 8,16\% tidak menyetujui. Hal ini menunjukkan bahwa lebih dari 90\% mahasiswa menyetujui pernyataan, sehingga dapat disimpulkan bahwa respon mahasiswa terhadap pembelajaran menggunakan borneo e-learning pada mata kuliah bahasa Inggris matematika positif. Sehingga dapat 
digunakan untuk perkuliahan online mata kuliah bahasa Inggris matematika selanjutnya.

Meski hasil temuan penelitian ini menunjukkan respon yang positif terhadap penggunaan Bel dalam perkuliahan bahasa Inggris matematika, ada hal yang harus diingat bahwa kendala utama mahasiswa adalah masalah akses internet yang tidak stabil. Dan masalah waktu Bel yang berbeda dengan real time, serta server sering down harus disampaikan kepada pihak pengembang untuk ditindaklanjuti. Bel sebagai salah satu platform LMS yang dapat dikembangkan oleh tim pusat pengembangan, hendaknya dimanfaatkan dan digunakan oleh para dosen internal dalam kegiatan pembelajaran/perkuliahan.

\section{DAFTAR PUSTAKA}

Arifin, M., \& Ekayati, R. (2019). E-Learning Berbasis Edmudo (1st ed.). Yogyakarta: Deepublish.

Bibi, S., \& Jati, H. (2015). Efektivitas Model Blended Learning Terhadap Motivasi dan Tingkat Pemahaman Mahasiswa Mata Kuliah Algoritma dan Pemrograman. Jurnal Pendidikan Vokasi, $5,74-87$.

Darmayasa, J. B., \& Aras, I. (2019). Panduan BEL (Borneo E-Learning). Pusat Pengembangan Kurikulum dan Pembelajaran Lembaga Pengembangan Pendidikan dan Penjaminan Mutu Universitas Borneo Tarakan.

Ekayati, R. (2018). Implementasi Metode Blended Learning Berbasis Aplikasi Edmudo. Jurnal EduTech, 4, 50-56.

Hartati, M. (2017). Respon Mahasiswa Mengenai Pelaksanaan Matrikulasi Bagi Mahasiswa baru IKIP PGRI Pontianak. Jurnal Edukasi, 15, 243-252.

Oktaviani, D. N., Sholikhakh, R. A., \& Lestiana, H. T. (2018). Persepsi Mahasiswa Terhadap Kepraktisan Learning Management System Moodle Berbasis Teori Behaviorisme. Jurnal Pendidikan Matematika, 6, 307-316.

Riyanti, A., \& Paramida, C. W. (2020). Analisis Penggunaan Media E-Learning Mata Kuliah Bahasa Indonesia Bagi Mahasiswa FKIP UBt Pada Masa Pandemi Covid 19. Jurnal Education and Development, 82-87.

Rizal, S., \& Walidain, B. (2019). Pembuatan Media Pembelajaran E-Learning Berbasis Moodle Pada Mata Kuliah Pengantar Aplikasi Komputer Universitas Serambi Mekah. Jurnal Ilmiah DIDAKTIKA, 19, 178-192.

Simanihuruk, L., Simarmata, J., Sudirman, A., Hasibuan, M. S., Safitri, M., Sulaiman, O. K., Ramadhani, R., \& Sahir, S. H. (2019). E-Learning:Implementasi, Strategi dan Inovasinya (1st ed.). Medan: Yayasan Kita Menulis. 